\title{
Institutional Mechanisms of the Turkish Foreign Policy: The Case of Russia - Turkey High-Level Cooperation Council
}

\author{
K. Aslanli, B. Akgün \\ Ankara Yildirim Beyazit University, Ankara, the Republic of Turkey
}

\begin{abstract}
The article aims to examine and explore with pros and cons of High-Level ("Strategic") Cooperation Councils (HLSCC) mechanisms in Turkish foreign policy and evaluate its effectiveness in foreign trade, foreign policy cooperation, and crisis management capacity of Turkey concerning the relations with Russia. Turkey has already started to establish High-Level Cooperation Councils to build institutional infrastructure for strategic partnerships in foreign policy and strengthen institutional power in the bilateral cooperation after 2006. The study of Turkish foreign policy is an academically attractive topic mostly in terms of its geopolitical dimensions. The institutional mechanisms that enable the country to interact with other states in a dynamic regional and international environment remain less researched heretofore. The article attempts to highlight the evolution of Turkish foreign policy in terms of institutional changes in the bilateral and multilateral mechanisms. The article applies a case study method with descriptive analysis examining Councils' functions such as foreign policy coordination and determination of collective commitments and official bilateral targets in the case of Russia - Turkey High-Level Cooperation Council. The article found out that these institutional mechanisms partly justified themselves as a coordination mechanism, but they were relatively weak for achieving the pledged commitments. The Councils were flexible and innovative cooperation mechanisms of the foreign policy to develop bilateral and multilateral ties in the age of the global power restructuring and the volatile conjuncture in world politics.
\end{abstract}

Key words: Turkish foreign policy, High-Level Strategic Cooperation Councils, institutional mechanism, Russia

For citation: Aslanli, K. \& Akgün, B. (2020). Institutional Mechanisms of the Turkish Foreign Policy: The Case of Russia - Turkey High-Level Cooperation Council. Vestnik RUDN. International Relations, 20 (4), $791-804$. DOI: $10.22363 / 2313-0660-2020-20-4-791-804$

\section{Институциональные механизмы внешней политики Турции: пример Совета сотрудничества высшего уровня Россия - Турция}

\author{
К. Асланлы, Б. Акгюн \\ Анкарский государственный университет им. Йылдырыма Беязыта, Анкара, Турецкая Республика
}

Статья посвящена исследованию плюсов и минусов механизмов Совета сотрудничества («стратегического») высшего уровня во внешней политике Турции и оценке их эффективности во внешней торговле, внешнеполитическом сотрудничестве и способности Турции управлять кризисами на примере отношений с Россией. Турция приступила к созданию Советов сотрудничества высшего уровня с целью создания институциональной инфраструктуры для стратегического партнерства во внешней политике и усиления институциональной основы в двустороннем сотрудничестве после 2006 г. Изучение внешней политики Турции является академически привлекательной темой в основном с точки зрения ее геополитического измерения.

(C) Aslanli K., Akgün B., 2020

This work is licensed under a Creative Commons Attribution 4.0 International License.

https://creativecommons.org/licenses/by/4.0/ 
Но ее институциональные механизмы, которые позволяют стране взаимодействовать с другими государствами в динамичной региональной и международной среде, до сих пор остаются менее изученными. В исследовании предпринята попытка осветить эволюцию внешней политики Турции с точки зрения институциональных изменений двусторонних и многосторонних механизмов. Применяется метод «конкретных ситуаций» с описательным анализом, в котором рассматриваются функции советов, такие как координация внешней политики и определение коллективных обязательств и официальных двусторонних целей на примере деятельности Совета сотрудничества высшего уровня между Россией и Турцией. Также выяснилось, что эти институциональные механизмы частично оправдали себя как механизм координации, но оказались относительно слабыми для выполнения взятых на себя обязательств. Советы являются гибкими и инновационными механизмами сотрудничества во внешней политике для развития двусторонних и многосторонних связей в эпоху перестройки глобального порядка и нестабильной конъюнктуры в мировой политике.

Ключевые слова: внешняя политика Турции, советы по стратегическому сотрудничеству высшего уровня, институциональный механизм, Россия

Для цитирования: Aslanli K., Akgün B. Institutional Mechanisms of the Turkish Foreign Policy: The Case of Russia - Turkey High-Level Cooperation Council // Вестник Российского университета дружбы народов. Серия: Международные отношения. 2020. Т. 20. № 4. С. 791-804. DOI: 10.22363/2313-0660-2020-20-4791-804

\section{Introduction}

The study of Turkish foreign policy is an academically attractive topic mostly in terms of its geopolitical dimensions. But its institutional mechanisms that enable the country to interact with other states in a dynamic regional and international environment remain less researched heretofore. Turkish foreign policy has been increasingly exploiting the combination of various diplomatic instruments in the last three decades. Starting after the collapse of the Soviet Union and the end of the Cold War, Turkey exploited international and regional organizations as a tool for its globalization. Also, it initiated bilateral and multilateral cooperation platforms such as the Economic Cooperation Organization (ECO), D-8 (the block of developing 8 countries), and the Black Sea Economic Cooperation Organization (BSEC).

After 2000, under the framework of "multivectorial" and multi-dimensional foreign policy approach, Turkey attempted to get a full membership from the European Union (EU) and then established an intense relationship with the Association of Southeast Asian Nations (ASEAN), Shanghai Cooperation Organization (SCO), and other regional organizations. Turkey took a temporary seat at the UN Security Council as a non-permanent member in the 2009-2010. Ruling political elites in Turkey from liberal to social democrat and conservative politicians often asserted that Turkey's global power is a "global reach" - to reach to every corner of the globe through international, regional, and bilateral organizational arrangements.

This policy requires building effective and institutional bilateral relations with strategic partner countries without rupture and disconnection from traditional international organizations which are also perceived to be more operative and suitable for interconnected world realities nowadays. The model that has been developing in the last decade is called High-Level Strategic Cooperation Councils (HLSCC) and High-Level Cooperation Councils (HLCC) which are new mechanisms in foreign policy-making and critical cooperation with partners ${ }^{1}$. HLSCCs are perfect reflections of Turkey's quests of "emerging power" during its problematic relations with Western partners. It can be claimed that councils were designed to get positive influences on the bilateral affairs and the increase of trade turnover of Turkey with a respective counterpart.

The current study attempts to answer the following research question: What are the rationales for Turkish foreign policy to establish high-level ("strategic") cooperation councils and

${ }^{1}$ Turkish foreign policy documents utilize HLSCC and HLCC as an interchangeable term. In this study, we will mostly refer to HLSCC, but the case study is about the Russia - Turkey High-Level Cooperation Council. From a methodological point of view, there is no inconsistency here, because both organizational formats have an identical institutional structure and functional mechanisms. 
which functions do these councils had to pursue to achieve high performances in the case of HLCC with Russia?

\section{Theoretical Foundations of Turkish Foreign Policy}

Turkish foreign policy has undergone drastic changes from a pro-Western stance to the multi-vectoral position in the last three decades. Various Turkish policymakers and decisionmakers formulated the country's foreign policy differently using "central state", "terminal state", "zero problems with neighbors", "supra-regional power" concepts meaning to act as a bridge or terminal state in the Eurasia region. Different concepts that were utilized to frame the foreign policy of Turkey theoretically indicate both the strengths and limits of Turkish foreign policy, especially in the neighboring regions [Cem 2004]. Turkey has followed multi-dimensional and dynamic foreign policy, considering the territorial integrity and equal status of regional states. The country attempted to develop humanitarian and economic relationships firstly in its region and then in the globe from a neoliberal perspective (it ranks as the first country in the world in terms of the ratio of donor assistance to GDP).

The power status of Turkey that also determines its foreign policy in the near region can be characterized as "rising power" and "middle power" with some structural constraints and limitations in regional order emanating from the region's chaotic environment that make it difficult to play a regional power broker role [Dal, Gok 2014].

As a "middle power", Turkey pursues a foreign policy towards alliance-building and balance of power among global powers [Balc1 2017]. Davutoglu categorized three methodological principles that drive Turkey's foreign policy ${ }^{2}$ : "visionary approach" to the foreign policy issues, instead of the "crisis-oriented approach"; "consistent and systematic" framework; "the

2 Davutoglu A. Turkey's Zero-Problems Foreign Policy // Foreign Policy. May 20, 2010. URL: https://foreignpolicy.com/2010/05/20/turkeys-zeroproblem-foreign-policy/ (accessed: 06.09.2020). adoption of a new discourse and diplomatic style" (soft power, civil-economic power, instead of military power).

The Minister of Foreign Affairs of Turkey M. Cavusoglu [2017] argues that the central principles of Turkish basic foreign policy have not changed despite the regional and global turmoil (he described new Turkish foreign policy as "enterprising and humanitarian"3). Keyman [2017] has emphasized that as a reaction to the new emerging security challenges in the Middle East and Europe, Turkey adopted a new foreign policy paradigm, "proactive moral realism", which fuses the elements of hard power and humanitarian norms designating more importance to the strategic security alliances.

Akgün [2009] indicated that Turkey's relationship with multilateral arrangements developing around political and security interests as a strategic tool and the search for identity. Kosebalaban pointed out that in the early years "The Justice and Development Party's (JDP) foreign policy was a response to changes in the international system, characterized by globalization and an increasingly multipolar international system" [Kosebalaban 2011: 146]. He argued that the synthesis of conservatism with liberalism has assured Turkey's hegemonic status.

Turkish foreign policy actively covered historical vital strategic interest zones such as Caucasus, Central Asia, the Middle East, Black Sea, and Balkans. Turkish foreign policy in the neighboring regions demonstrates the clash between strategic interest-driven policy and ideadriven policy. The various sets of coexisting strategic and material factors have shaped Turkish foreign policy towards its neighbors. For instance, Turkey has started to relinquish historically virulent perceptions of Russia and switches to shape a "pragmatically-minded strategic and economic partnership" making Russia Turkey's one of the largest trade partners

3 Opening speech of Mevlut Cavusoglu, Minister of Foreign Affairs at the 10th Ambassadors Conference // Ministry of Foreign Affairs of the Republic of Turkey. August 13, 2018. URL: http://www.mfa.gov.tr/data/ BAKAN/opening-speech-of-h-e-mevlut-cavusoglubkon.pdf (accessed: 06.09.2020). 
and natural gas providers ${ }^{4}$. The two countries started to implement various strategic projects such as building a nuclear power plant and the "Turkish Stream" natural gas pipeline. In this case, Turkey's foreign policy towards Russia is profoundly affected and deeply shaped by domestic political settings (the ruling party JDP that is led by President Erdogan has attitude to pursue a foreign policy independent from the Western powers), economic motivations (to promote export and diversify energy import), and regional security concerns (requisite cooperation and coordination with Russia at least in Syria, Libya, Caucasus (e.g. Karabakh conflict), and the Black Sea regions).

\section{The Rationale and Theoretical Foundations of High-Level Cooperation Councils}

Turkey devised different strategic cooperation platforms to contribute to the institutionalization of bilateral relations and to shape "cooperative behavior". Also, establishing HLSCC aligned with one of the declared goals of the Turkish foreign policy that was to solidify its position as a regional power and the transformation towards the global power status in the long-term using cemented regional alliances. Turkey on one hand initiated regional organizations (e.g. BSEC or ECO), and on the other hand established HLSCCs starting from 2006, as a sign of proactive and multidimensional foreign policy.

With these Councils, Turkey aimed to set up institutionalized strategic and heavily economic partnerships in foreign policy and to boost the firm commitments in bilateral cooperation with most important partner countries including Russia. High-level cooperation councils are institutional infrastructures of bilateral strategic relations. The Councils were extended joint cabinet meetings to debate bilateral and regional political, economic, and security issues. The Councils determine the strategic relationship between Turkey and partner countries in

4 Dirik G. The Windfall in Turkish-Russian Relations // Daily Sabah. August 08, 2019. URL: https:/www.dailysabah.com/op-ed/2019/08/08/the-windfallin-turkish-russian-relations (accessed: 06.09.2020). political, military, economic, commercial, energy, transportation, culture, science, and humanitarian fields and encourage the development and implementation of cooperation projects by the holistic strategy. Decisions are taken at the Council's meetings by discussing regional security issues, regional and international cooperation in the field, energy, transport, defense industry, military, trade and capital, education, and migration issues.

The council meetings, which are planned to be established in all neighboring countries, but not only, are aimed at dealing with all the problems in foreign policy. The agreements for the establishment of the HLSCCs also require that governments of the signatory countries meet at least once a year. In this way, the governments hold meetings of joint ministerial councils for all countries in the region and provide solutions to fundamental problems through dialogue. Turkey has established HLSCCs mostly with neighboring states, and through these councils, all countries in the region extending from the Balkans to the Middle East and Central Asia is going to realize the political and economic co-operation without security concerns.

Additionally, HLSCCs are high-level political and diplomatic platforms for both coordination and cooperation between the counterpart countries and Turkey. Councils implement functions of coordination and determination of collective commitments and targets. Turkey and important partner countries have agreed on the establishment of high-level strategic cooperation councils to further develop existing relations in all areas, ensuring long-term comprehensive integration and developing regional and international cooperation following mutual interests. Therefore, HLSCC is a complete integration tool between the concerned countries. Another aim is to develop cooperation in regional and international issues. In this context, the most significant achievement of Turkey would be to form bilateral or multilateral cooperation structures and mechanisms based on respective councils that we can name as "institutional scaling-up effect". HLSCCs were indications of Turkey's support on effective bilateralism and multilateralism against 
unilateralism in foreign policy. Councils are an innovative institutional and diplomatic mechanism to support Turkish foreign policy, to maintain a dynamic political and economic relationship.

Turkey maximized its efforts to rebuild mutually beneficial relationships with neighbors. It was intended to establish similar mechanisms with all neighboring countries, also to abolish visa requirements and to increase trade turnover with its neighbors and nearby regions. For the JDP foreign policymakers, high-level strategic cooperation councils provide a framework for a regional cooperation mechanism based on security, high-level political dialogue, economic integration, and interdependence principles. But Turkey constructed similar councils not only with neighbors but also with countries from other continents (e.g. Brazil from Latin America) meaning that the councils became generic foreign policy tools. Turkey aims to upgrade normal interstate relations to the highest degree of strategic partnership [Сафонкина 2014; Сажин, Карами 2017] using institutional mechanisms.

Turkey has established HLSCC and additional trilateral or quadrilateral collaborative processes with almost 30 partner countries. We must analyze the theoretical background of HLSCCs as an institutionalization of the Turkish foreign policy with primary partner countries. Eksi [2016] named High-Level Cooperation Councils "unique organizations" as a result of the JDP's multi-dimensional "international organization policy with neighboring countries" to develop common cooperation strategies. The primary function is to be an "instrument building institutional structure between countries" in the realist geopolitical level. HLSCCs are mechanisms for the institutionalization of Turkish foreign policy through stable organizational structure and systemization of collective actions with partner countries. HLSCC also indicate the very strong pragmatic dimension of Turkish foreign policy. Councils could be perceived as a part of Turkey's status-seeking strategies as an "emerging power" to boost its material capabilities and to influence "the dominant position of the hegemonic powers".

But the theoretical foundation of the highlevel strategic cooperation councils conforms more to the "trading state" concept. The "trading state" concept is applied to Turkish foreign policy by Kirişçi [2009] who pointed out that the "trading state" means "the state which cares about foreign policy and trade simultaneously and shaping foreign policy with economic dynamics". States that characterized as "trading state" give importance to the economic interdependence at foreign policy, instead of military capacity. Generally, the main determinants of interstate cooperation are economic (trade and investment) interdependence ("trading state" concept or liberal view), shared and followed common norms and values (constructivist view), and the possibility of limited cooperation (only if it conforms to national interest or if the state does not have the sufficient capacity to act autonomously - realist view).

Kuşku-Sönmez [2018] underlines that Councils contemplate achieving "enhanced, structured regularized cooperation to discuss all kinds of bilateral issues" including trade and investment issues. Turkey's mostly bilateral mechanisms have complementary logical interconnection with the role of international organizations in Turkish foreign policy. From the theoretical perspective, HLSCCs combine and build a consensus between the "trading state" concept from a liberal perspective and pragmatism from the neofunctionalist perspective.

HLSCCs are institutional mechanisms that serve economic cooperation and power-building at the regional level from a pragmatic and liberal functionalist perspective. High-level strategic cooperation councils are neo-liberal international regime-like institutions, but these are not fully multilateral. Institutions that have member states at regional levels also can be categorized as international regimes-like mechanisms [Moravcsik 1997; Stein 2008; Karns, Mingst, Stiles 2015; Tugtan 2016].

Interstate institutions or foreign policy mechanisms such as HLSCCs initiated by Turkey can increase the country's institutional power which is "actor's existing control over formal and informal institutions" and productive power that is the actor's ability to "create certain rules and norms to control behaviors" through these institutions [Chitty, Ji, Rawnsley, Hayden 
2017]. Institutionalized organs in the foreign policy can contribute to the foreign affairs agenda-setting and enhance its foreign policy motivations as intangible "soft power" resources [Nye 2011] and those cooperation councils can be seen as an influential "soft power" tool in the long run.

We could categorize four different, but interlinked functions that Turkey's high-level strategic cooperation councils could realize: strategic inter-state cooperation and rule-setting framework; commitment device, and coordination mechanism; first steps to building multilateral alliances to behave collectively; long-run "soft power" instrument. Also, HLSCCs as an institutional mechanism could contribute to the convergence of expectations and compliance with rules in bilateral intergovernmental issues. Therefore, the rule-setting function of HLSCCs can be a very important attribute if they will emerge new specialized policy-oriented commissions (e.g. on environmental protection) and other permanent bodies. If Turkey will succeed to sustain these councils in the long-run and if these institutional mechanisms would reflect broader societal demands for cooperation, it could be a more sustainable foreign policy arrangement.

\section{The Geography and Profiles of the High-Level Strategic Cooperation Councils}

Turkey has established HLSCC and alternative bilateral, trilateral, and quadrilateral multilateral cooperation mechanisms and collaborative processes with almost 30 partner countries [Ataman 2017]. 25 out of all these institutional mechanisms are high-level cooperation councils. Under the framework of the cooperation council, 60 meetings were held and the number of signed agreements was more than 500 up to 2019. The first HLCC was Turkey - Brazil High-Level Consultation Mechanism (2006). Turkey started to set up high-level strategic council meetings with Iraq, Syria, Greece, Bulgaria, Azerbaijan, Russia, and Ukraine after the second half of 2009.

The countries that Turkey has established high-level cooperation councils accounted for more than one-quarter $(25 \%)$ of Turkey's total annual trade turnover in 2019. It means the "trading state" concept is still a valid theoretical approach to explain the rationale why Turkey established high-level cooperation councils. But we must look at other criteria, as well, to better understand the establishment of these various institutional mechanisms that include not only high strategic cooperation councils but other mechanisms as well, to institutionalize its bilateral ties with foreign countries. These alternative criteria to establish higher strategic cooperation councils are geographic proximity (e.g. neighbor countries like Russia, Iraq, etc.), unique political relationship (e.g. Pakistan), leveraging ad hoc political and economic opportunities (e.g. Brazil), and supporting new opening towards "problematic" countries (e.g. Syria in 2009).

Turkey established high-level cooperation councils where mutual policy opportunities and dialogue environment existed. The belowmentioned table indicates that geographical coverage and the trade turnover with the partner countries that have Councils with Turkey surround mostly the MENA, the Caucasus and Central Asia, and Eastern and Southern Europe (Table 1).

In some cases, Turkish and partner countries' foreign ministers have formed a mechanism to promote the continuous development of bilateral relations and cooperative mechanisms to act continuously at the level of supporting mechanisms for the HLCC, Intergovernmental Summit, and Intergovernmental Joint Economic Commission. Turkey has actively used HLSCC as an institutional "damage control" and diplomatic "regeneration" mechanism to set new bilateral commitments (e.g. the official target about bilateral trade turnover) and adjust the solutions for bilateral challenging issues (such as water problem) that disrupt strategic cooperation. Turkey actively used HLSCCs as an institutional mechanism of bilateral relations

5 İki liderden işbirliğini geliştirme mesajı // Dunya Economic Newspaper. 03.01.2019. URL: https://www.dunya.com/gundem/iki-liderden-isbirliginigelistirme-mesaji-haberi-436360 (accessed: 15.09.2020). (На турецком языке). 
in foreign policy, especially with Central Asian, African, and Eastern European countries after 2016. To examine the functional performance of existing Councils, we will analyze the coordination and commitment functions in the case of a Russia - Turkey high-level cooperation council.

Turkey's High-Level Strategic Cooperation Councils and Other Similar Mechanisms

\begin{tabular}{|c|c|c|c|c|c|}
\hline Country & Mechanism & $\begin{array}{c}\text { Year of } \\
\text { establishment }\end{array}$ & Region & $\begin{array}{c}\text { Trade } \\
\text { turnover } \\
(2019), \\
\text { USD bln }\end{array}$ & $\begin{array}{c}\text { Share } \\
\text { in total } \\
\text { Turkish trade } \\
(\mathbf{2 0 1 9}), \%\end{array}$ \\
\hline Iraq & $\begin{array}{l}\text { High-Level Strategic Cooperation } \\
\text { Council }\end{array}$ & 2008 & Middle East & 11.515 & $3 \%$ \\
\hline Georgia & $\begin{array}{l}\text { High-Level Strategic Cooperation } \\
\text { Council }\end{array}$ & 2016 & $\begin{array}{l}\text { South } \\
\text { Caucasus }\end{array}$ & 1.637 & $0.44 \%$ \\
\hline Azerbaijan & $\begin{array}{l}\text { High-Level Strategic Cooperation } \\
\text { Council }\end{array}$ & 2010 & $\begin{array}{l}\text { South } \\
\text { Caucasus }\end{array}$ & 2.032 & $0.54 \%$ \\
\hline Lebanon & $\begin{array}{l}\text { High-Level Strategic Cooperation } \\
\text { and Coordination Council }\end{array}$ & $\begin{array}{c}2010 \\
\text { (no meeting) }\end{array}$ & Middle East & 1.08 & $0.29 \%$ \\
\hline Morocco & High-Level Strategic Council & $\begin{array}{c}2013 \\
\text { (no meeting) }\end{array}$ & North Africa & 2.998 & $0.8 \%$ \\
\hline Syria & $\begin{array}{l}\text { High-Level Strategic Cooperation } \\
\text { Council }\end{array}$ & $\begin{array}{c}2009 \\
\text { (no meeting } \\
\text { after 2010) }\end{array}$ & Middle East & 1.316 & $0.35 \%$ \\
\hline Qatar & High Strategic Committee & 2015 & Middle East & 1.427 & $0.38 \%$ \\
\hline Tunisia & $\begin{array}{l}\text { High-Level Strategic Cooperation } \\
\text { Council }\end{array}$ & 2012 & North Africa & 1.005 & $0.27 \%$ \\
\hline \begin{tabular}{|l|} 
Czech \\
Republic
\end{tabular} & $\begin{array}{l}\text { High-Level Strategic Cooperation } \\
\text { Council }\end{array}$ & 2013 & \begin{tabular}{|l|} 
Central / \\
Eastern Europe
\end{tabular} & 3.168 & $0.85 \%$ \\
\hline Hungary & $\begin{array}{l}\text { High-Level Strategic Cooperation } \\
\text { Council }\end{array}$ & 2013 & $\begin{array}{l}\text { Central / } \\
\text { Eastern Europe }\end{array}$ & 2.447 & $0.65 \%$ \\
\hline Kyrgyzstan & $\begin{array}{l}\text { High-Level Strategic Cooperation } \\
\text { Council }\end{array}$ & 2011 & Central Asia & 0.474 & $0.13 \%$ \\
\hline Kazakhstan & $\begin{array}{l}\text { High-Level Strategic Cooperation } \\
\text { Council }\end{array}$ & 2012 & Central Asia & 2.205 & $0.59 \%$ \\
\hline Pakistan & $\begin{array}{l}\text { High-Level Strategic Cooperation } \\
\text { Council }\end{array}$ & 2009 & South Asia & 0.803 & $0.21 \%$ \\
\hline Ukraine & $\begin{array}{l}\text { High-Level Strategic Cooperation } \\
\text { Council }\end{array}$ & 2011 & Black Sea & 4.559 & $1.2 \%$ \\
\hline Egypt & $\begin{array}{l}\text { High-Level Strategic Cooperation } \\
\text { Council }\end{array}$ & $\begin{array}{c}2011 \\
\text { (no meeting } \\
\text { after 2012) }\end{array}$ & North Africa & 5.129 & $1.4 \%$ \\
\hline Sudan & $\begin{array}{l}\text { High-Level Strategic Cooperation } \\
\text { Council }\end{array}$ & 2017 & North Africa & 0.364 & $0.09 \%$ \\
\hline Uzbekistan & $\begin{array}{l}\text { High-Level Strategic Cooperation } \\
\text { Council }\end{array}$ & 2018 & Central Asia & 2.212 & $0.59 \%$ \\
\hline Russia & High-Level Cooperation Council & 2010 & Eurasia & 26.306 & $7 \%$ \\
\hline Iran & High-Level Cooperation Council & 2014 & Middle East & 5.586 & $1.5 \%$ \\
\hline Saudi Arabia & $\begin{array}{l}\text { High-Level Strategic Dialogue } \\
\text { Mechanism (GCC) }\end{array}$ & 2008 & Middle East & 5.107 & $1.4 \%$ \\
\hline Bulgaria & High-Level Cooperation Council & 2012 & $\begin{array}{l}\text { The Black Sea } \\
\text { or Eastern } \\
\text { Europe }\end{array}$ & 4.879 & $1.3 \%$ \\
\hline
\end{tabular}


Асланль К., Акгюн Б. Вестник РУДН. Серия: Международные отношения. 2020. Т. 20. № 4. С. $791-804$

\begin{tabular}{|l|l|l|l|c|c|}
\hline \multicolumn{1}{|c|}{ Country } & \multicolumn{1}{|c|}{ Mechanism } & $\begin{array}{c}\text { Year of } \\
\text { establishment }\end{array}$ & \multicolumn{1}{|c|}{ Region } & $\begin{array}{c}\text { Trade } \\
\text { turnover } \\
(\mathbf{2 0 1 9 ) ,} \\
\text { USD bln }\end{array}$ & $\begin{array}{c}\text { Share } \\
\text { in total } \\
\text { Turkish trade } \\
\text { (2019), \% }\end{array}$ \\
\hline Greece & High-Level Cooperation Council & 2010 & Eastern Europe & 3.512 & $0.9 \%$ \\
\hline Serbia & High-Level Cooperation Council & 2017 & Eastern Europe & 1.264 & $0.34 \%$ \\
\hline Brazil & $\begin{array}{l}\text { High-Level Consultation } \\
\text { Mechanism }\end{array}$ & 2006 & Latin America & 3.074 & $0.8 \%$ \\
\hline Tajikistan & High-Level Cooperation Council & $\begin{array}{l}2012(\text { no } \\
\text { meeting) }\end{array}$ & Central Asia & 0.275 & $0.07 \%$ \\
\hline United States & $\begin{array}{l}\text { Ainisterial meeting (Framework } \\
\text { for Strategic Economic and } \\
\text { Commercial Cooperation) }\end{array}$ & $\begin{array}{l}2009 \text { ("model } \\
\text { partnership") }\end{array}$ & North America & 19.244 & $5.1 \%$ \\
\hline Italy & Intergovernmental Summit & 2008 & South Europe & 17.911 & $4.8 \%$ \\
\hline Spain & Intergovernmental Summit & 2009 & $\begin{array}{l}\text { Southern } \\
\text { Europe }\end{array}$ & 11.889 & $3.2 \%$ \\
\hline Portugal & Intergovernmental Summit & 2012 & $\begin{array}{l}\text { Southern } \\
\text { Europe }\end{array}$ & 1.795 & $0.48 \%$ \\
\hline Germany & Intergovernmental Summit & 2016 & $\begin{array}{l}\text { Western } \\
\text { Europe }\end{array}$ & 33.403 & $8.9 \%$ \\
\hline
\end{tabular}

Source: compiled by the authors based on reports of the Ministry of Foreign Affairs of Turkey. URL: http://www.mfa.gov.tr (accessed: 15.09.2020).

\section{Coordination and Commitment Functions of Councils: The Case of High-Level Cooperation Council between Russia and Turkey}

Turkey has established high-level cooperation councils with mostly neighbor countries such as Russia and some other counterparts that have a long distance from Turkey, as a continuation of an active new foreign policy that was initially reflected in intense cooperation with regional and international organizations. From an institutional point of view, high-level cooperation councils offer a platform for heads of states and governments, the "makers" of foreign policy, and technocrats/bureaucrats from line ministries of Russia and Turkey to convene annually and to discuss bilateral issues in the joint cabinet meetings format.

The Council deals with diversified policy areas varying from trade ("soft" policy area such as tourist flows from Russia to Turkey) to military cooperation ("hard" policy area such as Turkey's S-400 missile purchase from Russia). But in terms of the number of agreements and bilateral commitments, Council mostly concentrates on promoting bilateral economic agenda. Turkey intends to formulate economic prosperity and stability basins in the neighbouring region using economies of scale where Russia is a vital counterpart in the Black Sea and other regions. Onish [2011] and Hale [2012] emphasized the existence of a "strong impetus" and strategic interest to advance bilateral ties with Russia in the Caucasus and Central Asia region, as well.

Russian President and the Turkish Prime Minister signed a "Joint Statement on the establishment of a High-Level cooperation council between the Russian Federation and the Republic of Turkey" on May 12, 2010 ${ }^{6}$. Two countries relying on the deep traditions of friendship and good-neighborliness, striving to bring Russian-Turkish ties to a qualitatively new level, meeting the fundamental interests of the peoples of both countries, and guided by the goals and principles outlined in the Joint Declaration on the progress of relations between Russia and Turkey and further deepening

${ }^{6}$ Совместное заявление о создании Совета сотрудничества высшего уровня между Российской Федерацией и Турецкой Республикой // Президент России. 12.05.2010. URL: http://kremlin.ru/supplement/552 (дата обращения: 15.09.2020). 
of friendship and a multifaceted partnership of February 13, 2009, concluded on the establishment of a "High-Level Cooperation Council between Russia and Turkey". A new stage of the strategic partnership between Turkey and Russia was institutionalized with the establishment of a high-level cooperation council [Yeşiltaş, Balc1 2013].

The Council is the governing body developing the strategy and main directions for the development of relations between Russia and Turkey, coordinating the implementation of important projects of political, trade, economic, cultural, and humanitarian cooperation. Its activities should strengthen the partnership between the two countries, harmonize their actions to maintain regional stability and security. Taking into account the role of the Council as a fundamental element in the development of bilateral relations, the President of Russia and the Prime Minister of Turkey decided to head his Russian and Turkish parts respectively. Members of the governments of Russia and Turkey, responsible for the main issues under discussion, take part in the meetings of the Council. From an institutional point of view, it consists of the Joint Strategic Planning Group coordinated by ministers of foreign affairs; Joint Economic Commission led by related sectoral line ministries, and Turkey Russia Social Forum ${ }^{7}$.

But Russia - Turkey Joint Intergovernmental Commission on Trade and Economic Cooperation continues to be the principal mechanism for building practical cooperation in the economic sphere. Within the framework of the Council, the Joint Strategic Planning Group is set up under the leadership of Foreign Ministers to discuss the main issues of Russian-Turkish interaction in international affairs, which should be convened at least once a year. If necessary, the Group may hold meetings chaired by the Deputy Minister of Foreign Affairs of Russia and the Deputy Minister of Foreign Affairs of Turkey with the participation of representatives of other

7 Türkiye - Rusya Federasyonu ikili ilişkileri // Türkiye Cumhuriyeti Moskova Büyükelçiliği. 11.01.2019. URL: http://moskova.be.mfa.gov.tr/Mission/ShowInfoNote/ 219910 (accessed: 15.09.2020). (На турецком языке). interested ministries and departments. The leaders of the Commission and Group report to the Co-Chairs of the Council on the results of their work and proposals for further development of Russian-Turkish cooperation.

Taking into account the deep historical, cultural, and humanitarian ties between the two countries, the Public (Civil Society) Forum (Fig. 1) with the participation of representatives of academic and business circles, and civil society organizations will be established to further develop relations between peoples and civil society organizations of the two countries and ensure an atmosphere of productive dialogue. The public forum will work in coordination with the Council.

Council's meetings are organized once a year, alternately in Russia and Turkey. Under the framework of the subsequent Council meetings almost 50 intergovernmental agreements were signed and later adopted by Russia and Turkey: 1st meeting - May 11-12, 2010, Ankara; 2nd meeting - March 15-17, 2011, Moscow; 3rd meeting - December 3, 2012, Istanbul; 4th meeting - November 22, 2013, St. Petersburg; 5th meeting - December 1, 2014, Ankara; 6th meeting - March 10, 2017, Moscow; 7th meeting - April 3, 2018, Ankara; 8th meeting - April 8, 2019, Moscow.

Russia - Turkey bilateral relations dramatically deteriorated after downing a Russian jet in the Turkish border with Syria in November 2015. Russia suddenly started economic sanctions against Turkey that derogated bilateral trade turnover and tourist flows from Russia to Turkey and led to the suspension of bilateral projects such as the "Turkish Stream" natural gas supply project. The relations started mending after Turkish President Erdogan's official letter to the Russian President Vladimir Putin in July $2016^{8}$. Of course, we couldn't argue that HLCC was a determinant of the restoration of bilateral affairs in 2016, but that mechanism played the function of a diplomatic platform to adjust contrary interests.

\footnotetext{
${ }^{8}$ Russia Resumes Collaboration with Turkey // Daily Sabah. July 24, 2016. URL: https://www.dailysabah.com/ economy/2016/07/24/russia-resumes-collaboration-withturkey (accessed: 19.09.2020).
} 


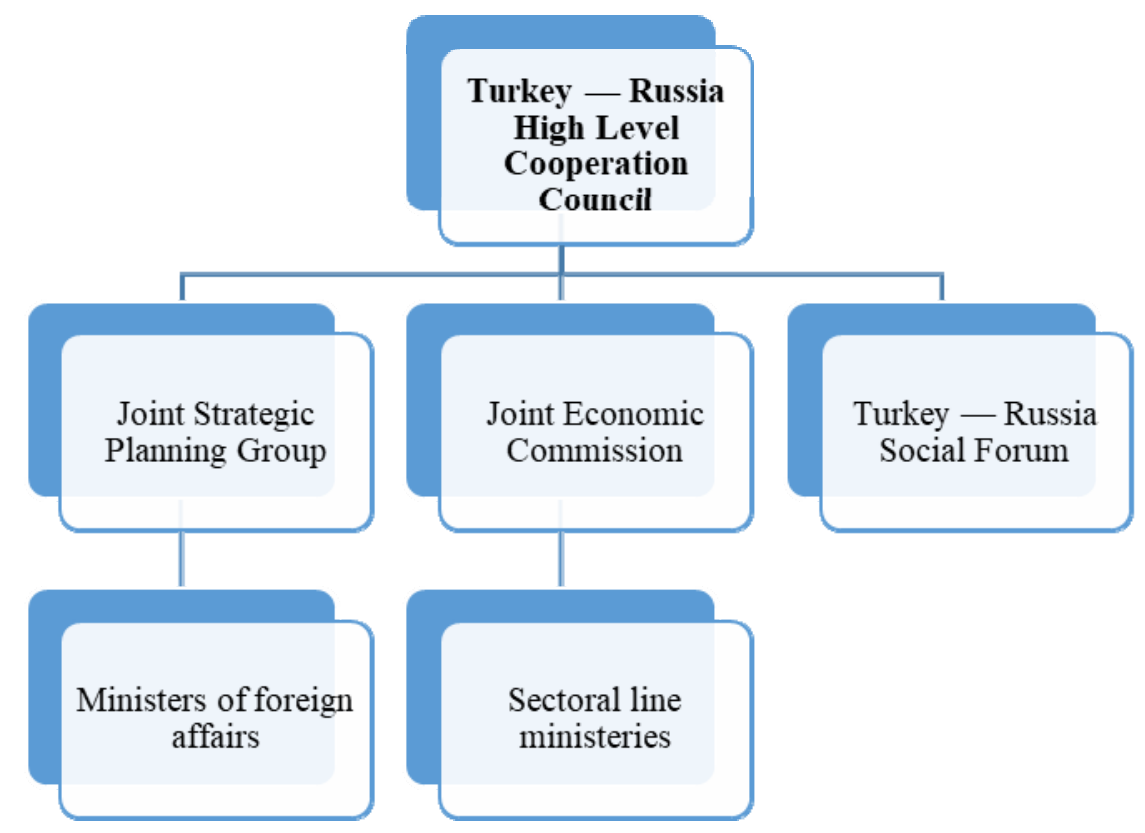

Fig. 1. The Structure of Turkey — Russia High-Level Cooperation Council Source: prepared by the authors.

Despite historical negative sentiments, the rapprochement between Turkey and Russia after the Cold War made Russia Turkey's one of the largest trade partners, an important natural gas provider, and a builder / supplier of nuclear energy capacity. These underlying economic factors partly formulate the foundations of bilateral affairs and bring the positions of the two countries in principal military and political conflicts closer. In this context, HLCC isn't a "game-changer" (e.g. it can't counterwork Turkey's shift from Russian pipeline gas to the US LNG), it is only an institutional mechanism as bilateral cooperation and interaction platform that facilitate conflict resolution and interest convergence.

Even though institutional foreign policy mechanisms such as HLSCCs couldn't prevent bilateral and multilateral conflicts, but these mechanisms can accelerate "the restoration" in the post-crisis period. After the initial signs of normalization of bilateral relations and the peak of crises, the Turkey - Russia High-Level Cooperation Council was effective coordination and confidence building platform to resume the broken cooperation between these two countries. Turkey and Russia didn't need to devise new institutional mechanisms about how to improve relations. They just used HLCC as an existing bilateral mechanism to trace and carry forward the previous agenda that was on the table before the "jet crises". After the resolution of the "jet crises" in 2016, Turkey's export to Russia increased by $60 \%$ and the number of Russian tourists/visitors in Turkey attained 4.7 million in $2017^{9}$. But in the mid-term period, Turkey Russia High-Level Cooperation Council couldn't create a fundamental move in the bilateral relations to solve all political, military, and energy disputes that widen from the Middle East to the South Caucasus.

List of documents signed by presidents and member of governments, also topics of discussion in the Turkey - Russia High-Level Strategic Council included policy fields such as

9 2017'de Türkiye'ye 32 milyon turist geldi // NTV. 31.01.2018. URL: https://www.ntv.com.tr/ekonomi/ 2017de-turkiyeye-32-milyon-turist-geldi,8vgRf5p72UGQT CI9MkccdQ (accessed: 20.08.2020). (На турецком языке); Ülkelere Göre İhracat İthalat. Türkiye - Rusya İhracat / İthalat İstatistikleri 2017 // Türkiye İstatistik Kurumu. 2017. URL: https://iz.tuik.gov.tr/\#/showcase/SC2851FY777F34D2R/db-s3abkab1c517y82? filters $=18792$ \%3D2017\%2618792\%3D2016\%2619283\%3D75\%20-\% 20Rusya $\% 20$ Federasyonu\&token $=8 \mathrm{~d} 79727 \mathrm{fff} 862 \mathrm{a} 891 \mathrm{ce} 5$ 74d27220bfebbf66fecd (accessed: 15.08.2020). (На турецком языке). 
energy (oil-gas pipelines, also the construction of "Akkuyu" nuclear power plant in Turkey), agriculture, transportation, readmission, cultural affairs, diplomatic relations, banking sector and finance (the establishment of a Russian-Turkish Investment Fund), joint actions of the Russia Turkey Public Forum, customs regimes, combating with the financing of terrorism, regional security and defense industry, and other areas. HLSCC has enabled the continuous communication channel between political leadership even during the bilateral crises in the case of Turkish-Russian relations.

\section{"Commitment function" of HLCC with Russia}

Turkey's high-level cooperation council with Russia has already proved itself as a coordination mechanism, but it was a relatively feeble mechanism for achieving the pledged commitments. Targets developed by the highlevel cooperation council, primarily to increase trade turnover or mutual investment flows were mostly formal and rarely achieved. Therefore, there is a need to establish a separate secretariat to follow up on the decisions made by the council and to provide updated analytical reports to the policymakers for promoting knowledgebased target-setting. For example, Russia and Turkey approved the official target to increase annual trade turnover from the proclaimed level to USD 100 billion by $2020^{10}$. The trade volume between the two countries reached USD 35 billion in 2018 but decreased to USD 26.3 billion in $2019^{11}$. Turkey was one of the main trade partners of Russia in January - July 2020 among non-CIS countries with trade

10 Türkiye - Rusya Üst Düzey İşbirliği Konseyi 4. Toplantısı St. Petersburgda gerçekleşti // Türkiye Cumhuriyeti Dişişleri Bakanlığı. 22.11.2013. URL: http://www.mfa.gov.tr/turkiye_rusya-ust-duzeyisbirligi-konseyi-dorduncu-toplantisi-st_petersburg_dagerceklestirildi.tr.mfa (accessed: 21.09.2020). (На турецком языке).

11 Cumhurbaşkanı Erdoğan, Rusya Devlet Başkanı Putin ile bir araya geldi // Türkiye Cumhuriyeti Cumhurbaşkanlığı. 08.04.2019. URL: https://www.tccb.gov. tr/haberler/410/103842/cumhurbaskani-erdogan-rusyadevlet-baskani-putin-ile-bir-araya-geldi 21.09.2020). (На турецком языке). turnover amounted to USD 11.3 billion $(79.1 \%$ compared to January - July 2019) ${ }^{12}$. Turkey and Russia couldn't achieve official targets on bilateral trade turnover that was adopted through high-level cooperation council.

In some cases, significant deviations between targeted and actual performance are the result of a non-realistic target setting that doesn't consider real economic challenges of counterpart countries and the global economy. The reliability of national statistical agencies of Turkey and Russia as a partner country also plays an important role. It is important to start regular work immediately through a joint commission to improve the quality and methodology of statistical data among the statistical institutions of Russia and Turkey. There are deviations in bilateral trade turnover from official targets with other partner countries with high-level cooperation councils, as well.

More realistic forecasts and official targets can be developed by taking into consideration some risks that may be experienced in the future especially due to external economic turbulence, and there is a need to react to these emerging risks quickly. The most important issue should be to reduce the proportion of future uncertainties in bilateral affairs through credible and mutual commitments. Commitments under the Council meetings should be compatible with the economic, technological, and political realities of both countries. Also, putting a solid political target for economic actors is auxiliary for motivating the business sector. HLCC has not relevant and solid institutional and organizational structure on the order of traditional and multilateral organizations (it lacks secretariats as agenda-setting and durable institutional memory). It very much depends on the "day-today" power relationship and attitudes of the political elites of Russia and Turkey towards each other on a bilateral level.

The main strength is that these councils function as a mechanism for a comprehensive

12 ФТС России: импорт - экспорт важнейших оваров за январь - июль 2020 года // Федеральная таможенная служба. 09.09.2020. URL: http:/customs.gov. $\mathrm{ru} / \mathrm{press} /$ federal/document/249806 (дата обращения: 21.09.2020). 
consultation, conflict resolution, and management (especially, in the case of Russia), "convergence of interests" and "damage control" in bilateral relations. This mechanism mitigates the damages and costs of bilateral political discords. But obviously, it is quite new mechanisms and current performance appraisals can be premature yet.

\section{Conclusion}

Turkish foreign policy has drawn the attention of scholars, journalists, and political pundits in a recent decade for many reasons. As a long-time NATO ally and a bastion of the Western block in the cold war years, Turkey's highly active and increasingly resilient foreign policy initiatives in the international arena created many debates regarding its strategic identity and domestic politics. Proactive and multi-dimensional foreign policy in new interest areas and geographies for Turkey - Africa, Middle East, Central Asia, Black Sea, Caucasus - created new competition between Turkey as an emerging middle power and traditional colonial powers.

The paper offers a political explanation by focusing on Turkey's unique and innovative cooperation and partnership model with its neighboring countries, and especially with Russia. Turkey attempted to cement its strong bilateral relations and set up crisis resolution instruments with Russia through the Council. It is an especially important mechanism in the period of increasing systemic anarchy and vague commitments in the global and regional power order. Turkey has been strengthening its institutional power in the region via its high-level strategic cooperation councils which have been established as a joint ministerial committee with various countries since 2006. Through setting up a high-level cooperation council, Turkey intends to transform bilateral institutional mechanisms into the nucleus of more extensive tribune to confer regional and global issues.

HLSCCs as the bilateral cooperation mechanisms are one of the new instruments of Turkey's multidimensional and cooperative foreign policy. At certain intervals, the councils of co-operation hold meetings at the level of heads of state and government, prime ministers or ministers. In these "joint cabinet of ministers meetings", serious decisions are taken on bilateral affairs, mutual agreements are signed, common policies and strategies are being set up. Relations with countries with strategic priorities are getting the institutional structure. In council meetings, problems and divergences between countries as well as areas of cooperation are deeply discussed by providing a mutual trust environment. HLSCCs are an extremely important step regarding establishing the institutional infrastructure of Turkey's bilateral strategic relations.

Turkey's high-level cooperation council with Russia partly proved it as a coordination mechanism, but it was a weak mechanism for achieving the pledged commitments. The highlevel cooperation council can operationalize and institutionalize foreign policy strategies and tactics of Turkey and Russia. The Council devised to solve collective action problems, to bring interests closer, and to respond to the social demands with Russia. To better reflect social demands, Turkey and Russia should strengthen the active functioning of the civil society forums within a high-level cooperation council. HLCC aims mostly to achieve high-level (formal) political dialogue, but there is a need to establish additional (less-formal) mechanisms to interact with non-state actors of Turkey and Russia.

HLSCC is innovative foreign policy mechanism that institutionalizes bilateral relations, but this mechanism is needed to be improved in three dimensions to extend: the fields and policy areas of cooperation; geographic scope; multistakeholder design (to involve civil society, academia, and business). There is a need to establish the "Special Permanent Secretariat" within the Ministry of Foreign Affairs of Turkey and Russia to lead and monitor the pledged commitments of the Council and to coordinate its comprehensive activities. Special Permanent Secretariat could perform as "early risk identification and warning mechanism" of the Councils to propose sensitive pro-active solutions to the emergencies and risky 
challenges in bilateral relations with Russia and other partner countries. It will take a time to convert the Councils to the resilient foreign policy mechanism to unravel the institutional fragmentation problem in bilateral relations and to frame a constructivist position accommodating the regional order.

Received / Поступила в редакцию: 20.09.2020

Accepted / Принята к публикации: 10.10.2020

\section{References}

Akgün, B. (2009). Türk Dış Politikası ve Uluslararası Örgütler. Akademik Orta Doğu, 3 (2), 1 - 40.

Balcı, A. (2017). Türkiye Dıș Politikası: Illkeler, Aktörler ve Uygulamalar. İstanbul: Alfa Yayıncıllk. (In Turkish). Cavusoglu, M. (2017). Turkish Foreign Policy in a Time of Perpetual Turmoil. Insight Turkey, 19 (1), 11-16.

Cem, I. (2004). Türkiye Avrupa Avrasya: Strateji, Yunanistan, Klbris. İstanbul: İstanbul Bilgi Üniversitesi Yayınları. (In Turkish).

Chitty, N., Ji, L., Rawnsley, G.D. \& Hayden, C. (2017). The Routledge Handbook of Soft Power. London: Routledge.

Dal, E.P. \& Gok, G.O. (2014). Locating Turkey as "Rising Power" in the Changing International Order: An Introduction. Perceptions: Journal of International Affairs, 19 (4), 1-18.

Eksi, M. (2016). The Rise and Fall of Soft Power in Turkish Foreign Policy During JDP. Riga: LAP Lambert Academic Publishing.

Hale, W. (2012). Turkish Foreign Policy since 1774. London: Routledge.

Karns, M.P., Mingst, K.A. \& Stiles, K.W. (2015). International Organizations: The Politics and Processes of Global Governance. Boulder, Co: Lynne Rienner Publishers.

Keyman, F. (2017). New Turkish Foreign Policy: Towards Proactive "Moral Realism”. Insight Turkey, 19 (1), 55—69.

Kirişçi, K. (2009). The Transformation of Turkish Foreign Policy: The Rise of the Trading State. New Perspectives on Turkey, 40, 29-56. DOI: 10.1017/S0896634600005203

Kosebalaban, H. (2011). Turkish Foreign Policy: Islam, Nationalism, and Globalization. London: Palgrave Macmillan.

Kuşku-Sönmez, E. (2018). Dynamics of Change in Turkish Foreign Policy: Evidence from High-Level Meetings of the JDP Government. Turkish Studies, 20 (3), 377-402. DOI: 10.1080/14683849.2018.1495078

Moravcsik, A. (1997). Taking Preferences Seriously: A Liberal Theory of International Politics. International Organization, 51 (4), 513-553. DOI: 10.1162/002081897550447

Nye, J. (2011). The Future of Power. New York: Public Affairs.

Onish, Z. (2011). Multiple Faces of the "New" Turkish Foreign Policy: Underlying Dynamics and a Critique. Insight Turkey, 13 (1), 47-65.

Safonkina, E. (2014). Turkey as a New Actor of Soft Power. International Organisations Research Journal, 9 (2), 145-166. (In Russian).

Sazhin, V. \& Karami, J. (2017). Iran-Russia Strategic Partnership at the New Stage: What Could We Propose to Each Other? Partnership between Russia and Iran: Current State and Development Prospects. Report of the Russian International Affairs Council, 29, 11-33. (In Russian). URL: https://russiancouncil.ru/common/ upload/RIAC-IRAS-Russia-Iran-Report29.pdf (дата обращения: 16.06.2020).

Stein, A. (2008). Neo-liberal Institutionalism. In: Reus-Smit, C. \& Snidal, D. (Eds.). Oxford Handbook on International Relations. New York: Oxford University Press. P. 201-221.

Tugtan, M.A. (2016). Kültürel Değişkenlerin Dış Politikadaki Yeri: İsmail Cem ve Ahmet Davutoğlu. Uluslararası İlişkiler, 13 (49), 3-24. (In Turkish).

Yeşiltaş, M. \& Balc1, A. (2013). Dictionary of Turkish Foreign Policy in the AK Party Era: A Conceptual Map. Ankara: SAM Papers.

Ataman, M. (2017). Editor's Note. Insight Turkey, 19 (1), 4-8.

\section{Библиографический список}

Сажин В., Карами Дж. Стратегическое партнерство России и Ирана на новом этапе: что мы можем предложить друг другу? // Партнерство России и Ирана: текущее состояние и перспективы развития. Доклад Российского совета по международным делам. 2017. № 29. С. 11-33. URL: https://russiancouncil.ru/ common/upload/RIAC-IRAS-Russia-Iran-Report29.pdf (дата обращения: 16.06.2020). 
Сафонкина E.A. Турция как новый актор политики «мягкой силы» // Вестник международных организаций. 2014. T. 9. № 2. C. $145-166$.

Akgün B. Türk Dış Politikası ve Uluslararası Örgütler // Akademik Orta Doğu. 2009. Cilt 3. Sayı 2. S. $1-40$. (На турецком языке).

Ataman M. Editor's Note // Insight Turkey. 2017. Vol. 19. Iss. 1. P. 4-8.

Balcı A. Türkiye Dış Politikası: İlkeler, Aktörler ve Uygulamalar. İstanbul: Alfa Yayıncılık, 2017. (На турецком языке).

Cavusoglu M. Turkish Foreign Policy in a Time of Perpetual Turmoil // Insight Turkey. 2017. Vol. 19. Iss. 1. P. $11-16$.

Cem I. Türkiye Avrupa Avrasya: Strateji, Yunanistan, Kıbrıs. İstanbul: İstanbul Bilgi Üniversitesi Yayınları, 2004. (На турецком языке).

Chitty N., Ji L., Rawnsley G.D., Hayden C. The Routledge Handbook of Soft Power. London: Routledge, 2017.

Dal E.P., Gok G.O. Locating Turkey as "Rising Power" in the Changing International Order: An Introduction // Perceptions: Journal of International Affairs. 2014. Vol. 19. Iss. 4. P. 1-18.

Eksi M. The Rise and Fall of Soft Power in Turkish Foreign Policy During JDP. Riga: LAP Lambert Academic Publishing, 2016.

Hale W. Turkish Foreign Policy since 1774. London: Routledge, 2012.

Karns M.P., Mingst K.A., Stiles K.W. International Organizations: The Politics and Processes of Global Governance. Boulder, Co: Lynne Rienner Publishers, 2015.

Keyman F. New Turkish Foreign Policy: Towards Proactive "Moral Realism" // Insight Turkey. 2017. Vol. 19. Iss. 1. P. 55-69.

Kirişçi K. The Transformation of Turkish Foreign Policy: The Rise of the Trading State. New Perspectives on Turkey. 2009. Vol. 40. P. 29-56. DOI: 10.1017/S0896634600005203

Kosebalaban H. Turkish Foreign Policy: Islam, Nationalism, and Globalization. London: Palgrave Macmillan, 2011.

Kuşku-Sönmez E. Dynamics of Change in Turkish Foreign Policy: Evidence from High-Level Meetings of the JDP Government // Turkish Studies. 2018. Vol. 20. Iss. 3. P. 377-402. DOI: 10.1080/14683849.2018.1495078

Moravcsik A. Taking Preferences Seriously: A Liberal Theory of International Politics // International Organization. 1997. Vol. 51. Iss. 4. P. 513-553. DOI: 10.1162/002081897550447

Nye J. The Future of Power. New York: Public Affairs, 2011.

Onish Z. Multiple Faces of the "New" Turkish Foreign Policy: Underlying Dynamics and a Critique // Insight Turkey. 2011. Vol. 13. Iss. 1. P. 47-65.

Stein A. Neo-liberal Institutionalism // Oxford Handbook on International Relations / Ed. by C. Reus-Smit, D. Snidal. New York: Oxford University Press, 2008. P. 201-221.

Tugtan M.A. Kültürel Değişkenlerin Dış Politikadaki Yeri: İsmail Cem ve Ahmet Davutoğlu // Uluslararası İlişkiler. 2016. Cilt 13. Say1 49. S. 3 -24. (На турецком языке).

Yeşiltaş M., Balcı A. A Dictionary of Turkish Foreign Policy in the AK Party Era: A Conceptual Map. Ankara: SAM Papers, 2013.

\footnotetext{
About the authors: Aslanli Kenan - PhD Candidate, Department of International Relations, Ankara Yildirim Beyazit University (e-mail: kenan.aslanli@yahoo.com).

Akgün Birol - PhD, Dr. of Sc. (Political Science), Professor, Department of International Relations, Ankara Yildirim Beyazit University (e-mail: birolakgun@hotmail.com).
}

Сведения об авторах: Асланлы Кенан - докторант кафедры международных отношений Анкарского государственного университета им. Йылдырыма Беязыта (e-mail: kenan.aslanli@yahoo.com).

Акгюн Бирол - доктор политических наук, профессор кафедры международных отношений Анкарского государственного университета им. Йылдырыма Беязыта (e-mail: birolakgun@hotmail.com). 